\title{
THE INFLUENCE OF ADMINISTRATORS' PERCEPTION OF THE CHILDREN ACT 8 OF 2001 ON THE IMPLEMENTATION OF THE GUIDANCE AND COUNSELLING PROGRAMME IN PUBLIC PRIMARY SCHOOLS IN EAST POKOT SUB-COUNTY, BARINGO COUNTY, KENYA
}

\author{
Maina Samuel Gitonga, \\ Enos Barasa Mukadi, \\ Prisca Tarus-Kiptoo \\ Department of Psychology, \\ Counselling \& Educational Foundations, \\ Laikipia University, \\ P.O. Box 1100-20300, Nyahururu, \\ Kenya
}

\begin{abstract}
:
The Government of Kenya is committed to ensuring that all children within her borders have access to their rights as detailed in the Convention on the Rights of the Child. School administrators in Kenya are mandated with the responsibility of managing primary school activities, as well as the task of ensuring the success of the school programmes and their perceptions greatly determines the success of the implementation of educational policies of guidance and counselling programmes. The purpose of this study was to determine the influence of administrators' perception of the Children Act 8 of 2001 on the implementation of the guidance and counselling programme in public primary schools in East Pokot Sub-county, Baringo County, Kenya. The study was guided by clientcentred approach theory and McGregor's Theory X and Y. The ex post facto research design was utilized. The target population under study comprised the 438 administrators in East Pokot Sub County. The total sample size was 280 respondents consisting of 140 head teachers and 140 teacher counsellors from 140 sampled schools. Purposive sampling was used to select head teachers and teacher counsellors from the five school divisions in East Pokot Sub-county. Questionnaires were used to collect data from the respondents. The instruments were pilot tested in 20 primary schools in the neighbouring Samburu County. The validity of the instruments was checked by the researcher through expert judgement from the department of Psychology, Counselling and Educational Foundations, Laikipia University. Reliability was determined by the use of the Cronbach coefficient alpha. The questionnaire was considered reliable after yielding a reliability
\end{abstract}

${ }^{i}$ Correspondence: email bamukadi2008@yahoo.com 
Maina Samuel Gitonga, Enos Barasa Mukadi, Prisca Tarus-Kiptoo

THE INFLUENCE OF ADMINISTRATORS' PERCEPTION OF THE CHILDREN ACT 8 OF 2001

ON THE IMPLEMENTATION OF THE GUIDANCE AND COUNSELLING PROGRAMME

IN PUBLIC PRIMARY SCHOOLS IN EAST POKOT SUB-COUNTY, BARINGO COUNTY, KENYA

coefficient alpha of 0.96 since a Cronbach alpha coefficient of 0.7 and above is considered sufficient to undertake the study. The Statistical Package for Social Sciences (SPSS) computer programme version 24.0 for windows was utilized to analyse the data. The data was analysed using descriptive and inferential statistics including percentages, means, and frequencies and simple regression which was tested at .05 level of significance. The study established that administrators' perception of the Children Act 8 of 2001 influenced the implementation of the guidance and counselling programme in public primary schools in East Pokot Sub-county, Baringo County, Kenya. Findings might benefit the County Ministry of Education officers, parents, teachers and other stakeholders in the implementation of guidance and counselling programme in primary schools. The study determined that in the respondents' opinion administrators' perception of the Children Act 8 of 2001 does significantly influence the implementation of the guidance and counselling programme in public primary schools in East Pokot Sub-county, Baringo County, Kenya. The study thus recommends that intensive awareness on the Children Act 8 of 2001 among the administrators in primary schools be carried out to enhance the implementation of the guidance and counselling programme in public primary schools in the region.

Keywords: Children Act, basic education, child neglect, child labour, cultural practice, early marriage, protecting children's rights

\section{Introduction}

The perception of the rights of the child is a relatively new global concept. However, the history of rights of the child dates back to the post First World War when millions of children were killed and many more injured, disfigured and made orphans, United Nations Children's Fund (UNICEF, 1996). This preceded the drafting of the Declaration of the Rights of the Child also known as the Geneva Declaration of the Rights of the Children which perceived children as special human beings that deserve protection for being minors (United Nations Population Fund, 2013). This international document that promoted the Rights of the Child was adopted by the League of Nations in 1924. Geneva Declaration of the Rights of the Children of 1924 stated in part, in times of distress children should be perceived differently from adults since they are vulnerable and they should be the first to receive relief during conflict or catastrophe, Save the Children (SC, 2019). This document was later extended and adopted by the United Nations in 1959. With this background, the United Nations Human Rights Commission group enhanced the global perception of the rights of the children by drafting the Convention on the Rights of the Child that was adopted by the United Nations General Assembly on 20th November 1989. It is essentially a commitment and a change in perception by signatory nations from grouping children with adults but as human beings in need of respect, protection for being minors to enable them to develop. 
Maina Samuel Gitonga, Enos Barasa Mukadi, Prisca Tarus-Kiptoo

THE INFLUENCE OF ADMINISTRATORS' PERCEPTION OF THE CHILDREN ACT 8 OF 2001

ON THE IMPLEMENTATION OF THE GUIDANCE AND COUNSELLING PROGRAMME

IN PUBLIC PRIMARY SCHOOLS IN EAST POKOT SUB-COUNTY, BARINGO COUNTY, KENYA

United Nations Convention of the Rights of the Child (UNCROC) outlines minimum standards in the areas of health, welfare, and education. States parties are expected to bring domestic laws, policies and practices in line with the standards and principles of UNCROC (Sarah, 2008). This expectation was taken up by African countries as they did not take an active role in the formulation of the Convention of the Rights of the Child (Kaime, 2009). As such, these rights of the child were based on western countries' experience of the abuse of children's rights in the two world wars, child labour in the industries and other western based situations. Lacking in the Convention of the Rights of the Child was the African social-cultural and religious ideologies. Consequently, the international norms respecting the promotion and protection of children's rights are heavily steeped in a 'Western' rights ideology and lack a meaningful African contribution (Lindsay, 2010).

Jerome (2012) noted that African states found it necessary to contextualize the convention on the Rights of the Child so that it reflected African perception of cultural heritage, historical background and the values of African civilization. This ideological and philosophical posturing motivated the adoption of the African Charter on the Rights and Welfare of the Child (ACRWC) by African states (Kaime, 2009). In 1990 the Organization of African Unity (OAU) adopted the African Charter on the Rights and Welfare of the Child. This Charter came into force in 1999 (Pkalya, 2010). By May 2013, the ACRWC had been ratified by forty-one (Kenya inclusive) of the fifty-four African Union States (Sakarai, 2010). Article one of the African Charter on the Rights and Welfare of the Child requires member states to recognize the rights, freedoms and duties enshrined in it. It also requires the states to take the necessary constitutional steps to adopt legislative measures necessary to give effect to its provisions by the individual states (UNCEF, 2014). This knowledge on the ACRWC can only be articulated through teachers in educational fora in schools.

Rasmussen (2010) has explained that the Dakar Framework for Action recommends nations to provide primary education of good quality and to improving all aspects of educational quality. Although there is no single definition of 'quality', most attempts to define it incorporates two fundamental perspectives. First, cognitive development is a primary objective of education, with the quality of education measured against its success in achieving this objective. Second, education must promote creative and emotional development, supporting the objectives of peace, citizenship and security, fostering equality and passing global and local cultural values down to future generations (Lindsay, 2010). These perspectives have been integrated into the aims of education set out in the Convention on the Rights of the Child, which formulates a philosophy of respect for children as individuals, recognizing each child as unique in characteristics, interests, abilities and needs (Sakurai, 2010). It sets out a framework of obligations to provide education that promotes children's optimum development.

Kenya has ratified most international treaties that protect the right to education, which form part of the country's laws (Republic of Kenya, 2002). The Constitution of 
Maina Samuel Gitonga, Enos Barasa Mukadi, Prisca Tarus-Kiptoo

THE INFLUENCE OF ADMINISTRATORS' PERCEPTION OF THE CHILDREN ACT 8 OF 2001

ON THE IMPLEMENTATION OF THE GUIDANCE AND COUNSELLING PROGRAMME

IN PUBLIC PRIMARY SCHOOLS IN EAST POKOT SUB-COUNTY, BARINGO COUNTY, KENYA

Kenya, in Article 53 (1) (b) states that every child has a right to free and compulsory basic education and Article 55 (a) the State shall take measures, including affirmative action programmes, to ensure that the youth access relevant education and training. Minorities and marginalized groups under Article 56 (b) have a right to be provided with special opportunities in the field of education. To give effect to the Constitution, the Basic Education Act (No 14 of 2013) has been passed into law to regulate the provision of basic education and adult basic education in the country. The Children's Act also acknowledges and protects every child's right to education. Other education laws guarantee the implementation of the right to education. Also, Kenya adopted various general and specific policies on education. The most recent is the second Medium Plan Term of Vision 2030 (2013) and the Policy Framework for Education and Training of 2012 (Mwenzwa and Misati, 2014). Kenya recognizes that education is the key for empowering the most marginalized and vulnerable individuals in society and make efforts on an affirmative basis to enable these individuals to best exploit their life-chances alongside their other Kenyan peers through primary, secondary and tertiary education.

The 2010 Constitution of Kenya recognizes that "every person has the right to education" (Article 43.1.f) and stipulates that "every child has the right to free and compulsory education" (Article 53.1.b). Also, "every child has the right to be protected from abuse, neglect, harmful cultural practices, all forms of violence, inhuman treatment and punishment, and hazardous or exploitative labour" (Article 53.1.d). Kenya has developed a comprehensive law and policy framework to protect and implement the guidance and counselling programme, which is aligned with international human rights treaties. However, the State faces challenges in enforcing these laws and policies. For instance, sexual abuse, early marriages, and pregnancies and gender stereotypes continue to affect a girl's education. Also, even after making primary and secondary education free, parents are still forced to pay some additional school fees. Other issues are a high ratio of teacher to pupils, poor teacher remuneration, poor quality of education in public schools, high drop-out and repetition rates, inadequate and uncoordinated funding with weak governance and financial management, geographical disparities, limited availability to teaching and learning material and limited community participation.

\section{Purpose of the Study}

The purpose of this study was to determine the influence of administrators' perception of the Children Act 8 of 2001 on the implementation of the guidance and counselling programme in public primary schools in East Pokot Sub-county, Baringo County, Kenya.

\subsection{Objectives of the Study}

The study was guided by the following research objective: 
Maina Samuel Gitonga, Enos Barasa Mukadi, Prisca Tarus-Kiptoo

THE INFLUENCE OF ADMINISTRATORS' PERCEPTION OF THE CHILDREN ACT 8 OF 2001

ON THE IMPLEMENTATION OF THE GUIDANCE AND COUNSELLING PROGRAMME

IN PUBLIC PRIMARY SCHOOLS IN EAST POKOT SUB-COUNTY, BARINGO COUNTY, KENYA

- To determine whether administrators' perception of the Children Act 8 of 2001 influences the implementation of the guidance and counselling programme in public primary schools in East Pokot Sub-county, Baringo County, Kenya.

To achieve the research objectives for this study, the following null hypothesis was posited and tested at .05 level of significance:

Ho1: Administrators' perception of Children Act 8 of 2001 has no statistically significant influences on the implementation of guidance and counselling programme in public primary schools in East Pokot Sub-county, Baringo County, Kenya.

\section{Research Methodology}

A research design is the blue print that explains how a research undertaking will be carried out. As has been pointed out by Burns and Grove (2001), a research design is one of the key enablers of research undertaking and consequently realization of the targeted outcomes. According to Sekeran (2003), descriptive research design is used to obtain information concerning the current status of the phenomena. Research design is a scheme, outline, or plan that is used to generate answers to the research problems (Orodho, 2004). This study research employed ex post facto research design. This is a research design, which looks into incidents that have already occurred and therefore, cannot be manipulated by the researcher (Kothari, 2004). This design is particularly suitable in social, educational and psychological contexts where the independent variable or variables lie outside the researcher's control. In this study, the independent variable was administrators' perception of the Children Act 8 of 2001, while the dependent variable was the implementation of educational policies of guidance and counselling. Therefore, the researcher proceeded to study the independent variable in retrospect for their possible relationship and impact on the dependent variable.

\subsection{Population, Sample Size and Sampling Procedures}

The population under study comprised of the 438 administrators in East Pokot Sub County. This constituted the target population of the study. The research utilized purposive and stratified random sampling procedures in the selection of the required study sample. Stratified random sampling is used when a sample is taken from a stratum. It is easier to achieve precision through stratification if the strata are chosen to ensure that members or items in the same stratum are similar in respect to characteristics. The method proposed by Kathuri and Pals (1993) was used to determine the sample size of the administrator. Kathuri and Pals (1993) established a guide for determining the sample size that is randomly chosen from a limited population. Based on Kathuri and Pals's approach, out of 219 primary schools, 140 schools were identified which gave a sample of 280 respondents for participation in the study. Thus, 140 head teachers and 140 teacher counsellors were selected. As emphasized by Mugenda and Mugenda (2012), The purposive sampling method allows the researcher to use cases that have the required 
Maina Samuel Gitonga, Enos Barasa Mukadi, Prisca Tarus-Kiptoo

THE INFLUENCE OF ADMINISTRATORS' PERCEPTION OF THE CHILDREN ACT 8 OF 2001

ON THE IMPLEMENTATION OF THE GUIDANCE AND COUNSELLING PROGRAMME

IN PUBLIC PRIMARY SCHOOLS IN EAST POKOT SUB-COUNTY, BARINGO COUNTY, KENYA

characteristics based on the objective of their study. Purposive sampling was used because the head teachers were automatically included in the research since each public primary school had one head teacher. Teacher counsellors, on the other hand, were purposively selected because they were the primary administrators of school guidance and counselling activities.

\subsection{Instrumentation}

The primary data for analysis were obtained from the respondents through the use of structured questionnaires. The questionnaires had different sections. The first part collected some necessary detail of the respondents. The questionnaires were preferred because they allowed the collection of data from a larger sample of individuals. Creswell (2002) defines data collection as a means by which information is obtained from the selected subjects of an investigation. Each instrument targeted specific information from the respondents. Each question was designed to address specific objectives and hypotheses of the study. The questionnaires were open and closed-ended to gather both quantitative and qualitative information. The questionnaires were supplemented by questions which purposely provided in-depth information important for the study. The others adopted were the Likert scale, dichotomous, multiple choice, and open-ended types. Likert scale is useful for measuring perceptions and attitudes. A Likert-type scale assumes that the strength of experience is linear therefore the research used a continuum from 'strongly agree' to 'strongly disagree'. Content analysis was used as an instrument in this study to make valid inferences by evaluating and interpreting the textual materials in the questionnaire.

\subsection{Validity and Reliability of the Instruments}

The research instruments were systematically evaluated to ensure that they are valid. A valid instrument is paramount to ensure that the data collected accurately samples out the desired attributes of the population (Borg \& Gall, 2007). Also, the validity of a test is a measure of how well a test measures what it is supposed to measure (Kombo \& Tromp, 2006). In this study, the validity tested was content validity. As emphasized by Krippendorff (2018) content validity helps the researcher to quantify and analyse the presence, meanings and relationships of such words and concepts, then make inferences about the messages within the texts. In this regard, content validity of the instruments that was used, was done through the expert judgment by the supervisors and colleagues in the department of Psychology Counselling and Educational Foundations who examined whether or not the research instruments represented the full content of the study. Their advice was used to modify the instrument to address the research hypotheses as deemed fit.

Reliability refers to the measure of the degree to which a research instrument yields consistent results or data after repeated trials (Mugenda \& Mugenda, 1999). Reliability is a measure of the accuracy of the findings and suggests the truthfulness of 
Maina Samuel Gitonga, Enos Barasa Mukadi, Prisca Tarus-Kiptoo

THE INFLUENCE OF ADMINISTRATORS' PERCEPTION OF THE CHILDREN ACT 8 OF 2001

ON THE IMPLEMENTATION OF THE GUIDANCE AND COUNSELLING PROGRAMME

IN PUBLIC PRIMARY SCHOOLS IN EAST POKOT SUB-COUNTY, BARINGO COUNTY, KENYA

the collected data whereas validity is the measure of acceptability whether the outcomes are likely to be adopted for similar cases or areas covering the same domains. Reliability gives a measure of the accuracy of the test procedure and ensures the degree of precision of the outcomes. According to Kombo and Tromp (2006) reliability is a measure of how consistent the results from tests are. The researcher employed the internal consistency method to test reliability. A pilot study was conducted in the neighbouring Samburu County. The pilot study was done in ten schools, which were similar to the actual sample of the study. The questionnaires were pre-tested first; the procedure that was used in pretesting the questionnaires was identical to that which was used during the actual study. This helped the researcher to have meaningful observations. It also helped to detect deficiencies in the questionnaire, such as unclear directions and insufficient space to write the responses. Piloting helped in determining the reliability of the instruments. The reliability of the instruments was examined using the Cronbach alpha coefficient. The questionnaires' items were considered reliable after yielding a Cronbach alpha coefficient level of 0.96. According to Saunder et al. (2009), a Cronbach alpha coefficient of 0.7 and above is considered sufficient to undertake the study. Hence, the questionnaire was deemed reliable.

\subsection{Data Collection Procedure}

The researcher obtained an introductory letter from Laikipia Graduate School then sought a permit from the National Commission for Science, Technology, and Innovation (NACOSTI). Permission to collect data from schools was obtained from the County Director of Education Baringo. The researcher personally administered the questionnaires to the respondents. The filled-in questionnaires were collected at the same time.

\section{Results and Discussions}

This section presents the findings, results and discussions related to the objectives of the study. The collected data were analysed using both descriptive and inferential statistics aided by Statistical Package for Social Sciences (SPSS) computer programme version 24.0 for windows. The hypothesis was tested using simple regression analysis. The hypothesis tests were performed at a significant level of $\alpha=.05$. The null hypotheses were rejected or failed to be rejected based on calculated test statistics and the value of probability of significance ( $\mathrm{p}$-value). Null hypothesis failed to be rejected when $\mathrm{p} \geq .05$ and rejected when $\mathrm{p}<.05$.

\subsection{Demographic Characteristics of the Respondents}

This section gives a summary of the distribution of the respondents in terms of demographic characteristics. The demographic information was key in explaining the emerging trends in the study results. The research targeted 140 head teachers and 140 
Maina Samuel Gitonga, Enos Barasa Mukadi, Prisca Tarus-Kiptoo

THE INFLUENCE OF ADMINISTRATORS' PERCEPTION OF THE CHILDREN ACT 8 OF 2001

ON THE IMPLEMENTATION OF THE GUIDANCE AND COUNSELLING PROGRAMME

IN PUBLIC PRIMARY SCHOOLS IN EAST POKOT SUB-COUNTY, BARINGO COUNTY, KENYA

teacher counsellors from 140 Primary schools in East Pokot Sub County. Purposive sampling was used to select 280 respondents i.e. 140 head teachers and 140 counsellors in 140 primary schools.

The objective of the study was to determine whether administrators' perception of the Children Act 8 of 2001 influences the implementation of the guidance and counselling programme in public primary schools in East Pokot Sub-county, Baringo County, Kenya. Guidance and counselling activities instil discipline in primary school pupils. The objective was measured by eight items which were presented to the respondents. The questions presented to the respondents constituted whether children's right to education should be emphasized in the guidance and counselling programme; the right to participate in the school decision making process should be emphasized in counselling sessions; all boys have a right to go through circumcision according to customs; it is in order for a girl to get married soon after circumcision; the community does not support basic education for their children; many primary school going children lack good parental care; right to good health care is a big problem to many primary pupils; and, that boys drop out of school to become community defenders in cattle rustling.

To achieve this objective the following hypothesis was formulated:

Ho1: Administrators' perception of the Children Act 8 of 2001 has no statistically significant influence on the implementation of the guidance and counselling programme in public primary schools in East Pokot Sub-county, Baringo County, Kenya.

The hypothesis presumed that Administrators' perception of the Children Act 8 of 2001 has no statistically significant influence on the implementation of the guidance and counselling programme in public primary schools in East Pokot Sub-county, Baringo County, Kenya.

To establish the truth of this assumption, a simple regression analysis test was carried out. The results of the analysis are as shown in Tables 1 and 2.

Table 1 presents the means of administrators' perception of the Children Act 8 of 2001 and their implementation of the guidance and counselling programme in public primary schools in East Pokot Sub-county, Baringo County.

Table 1 indicates the highest means of administrators' perception of the Children Act 8 of 2001 and their implementation of the guidance and counselling programme in public primary schools in East Pokot Sub-county, Baringo County was that Children's right to education should be emphasized in Guidance and Counselling programme (mean $=4.2143$ ), implying that majority of the respondents agree that children right to education was a major determinant of the administrators' perception of the Children Act 8 of 2001 and their influences on the implementation of guidance and counselling in schools in East Pokot Sub-county Baringo County, Kenya should be emphasized in guidance and counselling programme is a major determinant, followed by the view that the right to participate in the school decision making process should be emphasized in counselling sessions (mean $=3.78570$ ); followed by the feeling that all boys have a right to go through circumcision according to customs (mean $=3.4107$ ); and, the view that it 
Maina Samuel Gitonga, Enos Barasa Mukadi, Prisca Tarus-Kiptoo

THE INFLUENCE OF ADMINISTRATORS' PERCEPTION OF THE CHILDREN ACT 8 OF 2001

ON THE IMPLEMENTATION OF THE GUIDANCE AND COUNSELLING PROGRAMME

IN PUBLIC PRIMARY SCHOOLS IN EAST POKOT SUB-COUNTY, BARINGO COUNTY, KENYA

was in order for a girl to get married soon after circumcision with a mean of 3.3500. The feeling that the community did not support basic education for their children (mean = 2.9393) came fifth. Further the last three items were that many primary school going children lacked good parental care with a mean of 2.7536; right to good health care was a big problem to many primary pupils (mean $=2.7214$ ); and, boys drop out of school to become community defenders in cattle rustling(mean $=2.4571$ ) respectively.

Table 1: Means of Administrators' Perception of the Children Act 8 of 2001 and their influences on the Implementation of the Guidance and Counselling Programme in Public Primary Schools

\begin{tabular}{|l|c|}
\hline Children Act $\mathbf{8}$ of $\mathbf{2 0 0 1}$ & Mean \\
\hline $\begin{array}{l}\text { Children's right to education should be emphasized in the Guidance } \\
\text { and Counselling programme. }\end{array}$ & 4.2143 \\
\hline $\begin{array}{l}\text { The right to participate in the school decision making process should } \\
\text { be emphasized in counselling sessions. }\end{array}$ & 3.7857 \\
\hline All boys have a right to go through circumcision according to customs. & 3.4107 \\
\hline It is in order for a girl to get married soon after circumcision. & 3.3500 \\
\hline The community does not support basic education for their children. & 2.9393 \\
\hline Many primary school going children lack good parental care. & 2.7536 \\
\hline Right to good health care is a big problem to many primary school pupils. & 2.7214 \\
\hline Boys drop out of school to become community defenders in cattle rustling. & 2.4571 \\
\hline Grand Total & $\mathbf{3 . 2 2 0}$ \\
\hline
\end{tabular}

Source: (Field data, 2020)

Table 2 presents simple regression between administrators' perception of the Children Act 8 of 2001 and their influences on the implementation of guidance and counselling in schools in East Pokot Sub-county, Baringo County, Kenya.

Table 2 indicates that the Pearson correlation coefficient administrators' perception of the Children Act 8 of 2001 and their influences on the implementation of guidance and counselling in schools in East Pokot Sub-county, Baringo County, Kenya was statistically significant at .05 level of significance $(r=.414, p=0.000)$. The $r$ squared was found to be 0.171 . This indicates that $17.1 \%$ of the variance in administrators' perception of the Children Act 8 of 2001 and their influences on the implementation of guidance and counselling programme.

In addition, Table 2 presents Regression analysis of administrators' perception of the Children Act 8 of 2001 and their influences on the implementation of the guidance and counselling programme in schools in East Pokot Sub-county, Baringo County, Kenya.

Moreover, from Table 2, the F value was found to be significant $(F(1,279)=57.540$, $\mathrm{p}=.000)$. Therefore null $\left(\mathrm{H}_{0} 5\right)$ that administrators' perception of the Children Act 8 of 2001 has no statistically significant influence on the implementation of the guidance and counselling programme among public primary schools in East Pokot Sub-county, Baringo County was rejected at .05 significance level and the alternative hypothesis that administrators' perception of the Children Act 8 of 2001 has statistically significant 
influences on the implementation of guidance and counselling in public primary schools in East Pokot Sub-county, Baringo County, Kenya was accepted at 0.05 level of significance. It was therefore concluded that administrators' perception of the Children Act 8 of 2001 does significantly influence Implementation of the Guidance and Counselling Programme in primary schools in East Pokot Sub-county, Baringo County, Kenya.

Table 2: Simple Regression Analysis of Administrators' Perception of the Children Act 8 of 2001 and their Influences on the Implementation of the Guidance and Counselling Programme in Public Primary Schools

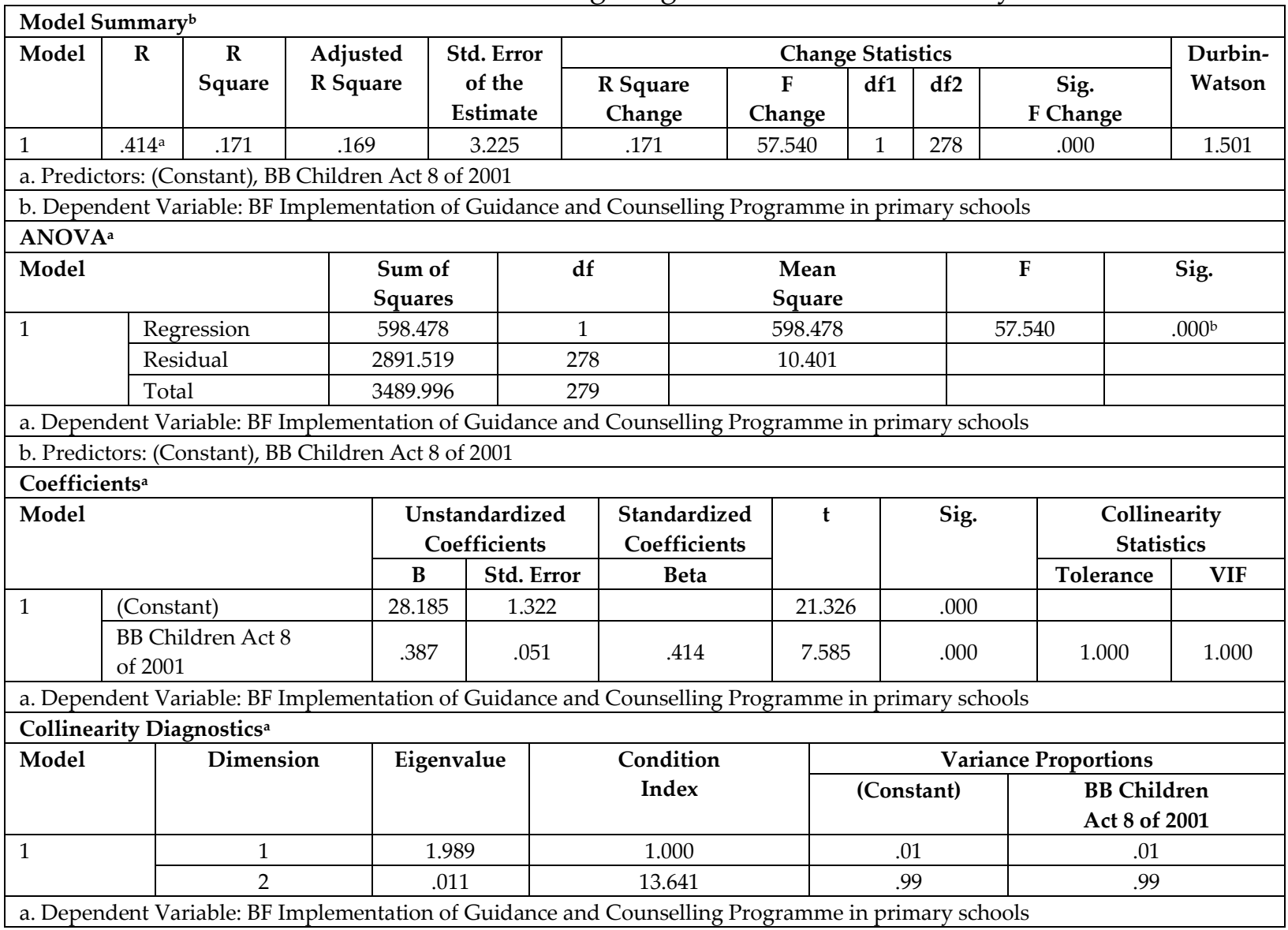

Source: (Field data, 2020)

The unstandardized beta coefficients indicate that administrators' perception of the Children Act 8 of $2001(\beta=0 . .051, p<0.05)$ was a statistically significant predictor of Implementation of the Guidance and Counselling Programme in primary schools in East Pokot Sub-county, Baringo County, Kenya. When there is a unit increase in administrators' perception of the Children Act 8 of 2001, implementation of Guidance and Counselling in primary schools in East Pokot Sub-county, Baringo County, Kenya will increase by .051 units. Therefore, the simple linear regression results in Table 2 show that the administrators' perception of the Children Act 8 of 2001 has statistical positive significant influence on implementation of the Guidance and Counselling Programme in 
Maina Samuel Gitonga, Enos Barasa Mukadi, Prisca Tarus-Kiptoo

THE INFLUENCE OF ADMINISTRATORS' PERCEPTION OF THE CHILDREN ACT 8 OF 2001

ON THE IMPLEMENTATION OF THE GUIDANCE AND COUNSELLING PROGRAMME

IN PUBLIC PRIMARY SCHOOLS IN EAST POKOT SUB-COUNTY, BARINGO COUNTY, KENYA

primary schools in East Pokot Sub-county, Baringo County, Kenya. This suggests that the implementation of guidance and counselling programme in primary schools in East Pokot Sub-county, Baringo County, Kenya is positively linked to administrators' perception of the Children Act 8 of 2001. Moreover, Table 2 indicates that there was no multi-collinearity as shown by tolerance $(\mathrm{T}>0.2)$ and Variance Inflation Factor $(\mathrm{VIF}<10)$. It was therefore concluded that administrators' perception does influence their implementation of the Guidance and Counselling Programme in primary schools. This indicates that, administrators who were aware and had positive perception of the Children Act 8 of 2001 were likely to implement a guidance and counselling programme in public primary schools.

This finding is in agreement with what Victoria (2015) reported in her study that administrators were positive in 15 items but negative in 7 items of the questionnaire. This result gave a proportion of $68 \%$ positive and $32 \%$ negative. The study determined that teachers' awareness of right of children to education, love, socialize, life, shelter, security, good health care and parental care did influence their perception of the rights of children in the guidance and counselling programme. It was therefore concluded that teachers' awareness does influence their perception of rights of children in the guidance and counselling programme. This indicates that, senior teachers, despite their awareness of rights of the child, are likely to protect and enhance access to the rights of children in the guidance and counselling programme in public primary schools. This means all teachers' awareness of rights of the child influence perception and would support the implementation of the rights of the children in the guidance counselling programme.

The right to education entails an inclusive and holistic approach to education, as demonstrated in Article 26 of the United Nations Declaration of Human Rights: "Education shall be directed to the full development of the human personality and to the strengthening of respect for human rights and fundamental freedoms" (UDHR 1948, page 8). Every child in whatever educational setting has the fundamental right to quality education provided by quality teachers. Local and national education laws must be in line with international human rights treaties. Quality education is both a fundamental right for all, and an essential enabler for the achievement of other rights. States are obliged, collectively and individually, to make quality education available to all, at all levels, free of charge. In policy and practice quality education needs inputs (including adequate investment in public education, safe and healthy schools with adequate infrastructure, facilities and resources as well as qualified and well-supported teachers) coupled with a comprehensive and inclusive teaching and learning process. The universal right to education for all includes equitable participation in quality education. Therefore, all children and young people, including those from poor households, girls and boys, disabled children, children in rural and remote locations, conflict and postconflict situations must have equitable access to quality education. This includes early childhood, primary, lower and upper secondary, vocational, higher and adult education. An inclusive and diverse classroom with an appropriate curriculum allows learners to 
Maina Samuel Gitonga, Enos Barasa Mukadi, Prisca Tarus-Kiptoo

THE INFLUENCE OF ADMINISTRATORS' PERCEPTION OF THE CHILDREN ACT 8 OF 2001

ON THE IMPLEMENTATION OF THE GUIDANCE AND COUNSELLING PROGRAMME

IN PUBLIC PRIMARY SCHOOLS IN EAST POKOT SUB-COUNTY, BARINGO COUNTY, KENYA

interact with different people, understand themselves and the world, and forms the basis for a sense of shared values and a deepened intercultural awareness (Teacher matter, 2012).

In addition, the finding of this study concurs with UNESCO's research findings of $2005 \mathrm{~b}$ that the school enrolment for primary education is not only related to family factors such as low income but also the school administration. As noted by Khan (2015), family income has substantial but decidedly selective associations with children's attainments. The selective nature of effects included the following: Family income had much larger associations with measures of children's ability and achievement than with measures of behaviour, mental health and physical health. Due to poverty, parents are unable to meet both direct and indirect costs of schooling which forces them to withdraw the children from the school system so as to contribute to family income hence low transition rate. The study also observed that when the children stay at home, they contribute to family income through working and therefore the parents weigh the cost and benefits of keeping them at home to work or sending them to school. Thus, guidance and counselling at the school will enlighten the pupils hence easier implementation of guidance and counselling since more pupils will be available. This is as a result of effort which has been directly made by the administrator due to their perception of the Children Act 8 of 2001. It is therefore evident that the perception of the administrator of the Children Act 8 of 2001 influences the implementation of the guidance and counselling programme in public primary schools in East Pokot Sub-county, Baringo County, Kenya.

\subsection{Summary of the Findings}

The objective of the study was to determine whether administrators' perception of the Children Act 8 of 2001 influences the implementation of guidance and counselling programmes in public primary schools in East Pokot Sub-county, Baringo County, Kenya.

To achieve this objective the following hypothesis was formulated:

Ho1: Administrators' perception of the Children Act 8 of 2001 has no statistically significant influence on the implementation of guidance and counselling programmes in public primary schools in East Pokot Sub-county, Baringo County, Kenya.

The hypothesis was tested using ANOVA test. The ANOVA test showed that:

1) The $F$ value was found to be significant $(F(1,279)=57.540, p=.000)$.

2) The null hypothesis $\left(\mathrm{H}_{0} 5\right)$ was rejected.

3) That Administrators' perception of Children Act 8 of 2001 has influences on the implementation of guidance and counselling programme in public primary schools in East Pokot Sub-county, Baringo County, Kenya. 


\section{Conclusions}

Administrators' perception of the Children Act 8 of 2001 does significantly influence the implementation of guidance and counselling programmes in public primary schools in East Pokot Sub-county, Baringo County, Kenya.

\subsection{Recommendations}

The study determined that in the respondents' opinion administrators' perception of the Children Act 8 of 2001 does significantly influence the implementation of the guidance and counselling programme in public primary schools in East Pokot Sub-county, Baringo County, Kenya. The study thus recommends that intensive awareness on the Children Act 8 of 2001 among the administrators in primary schools be carried out to enhance the implementation of the guidance and counselling programme in public primary schools in the region.

\subsection{Recommendations for Further Research}

Research should also be conducted to determine whether administrators' professional experience affects their perception of the Children Act 8 of 2001 which also influences the implementation of guidance and counselling programmes in public primary schools in East Pokot Sub-county, Baringo County, Kenya.

\section{Conflict of Interest Statement}

The authors declare no conflicts of interests.

\section{About the Author}

The author is a PhD student of Guidance and Counselling Psychology.

\section{References}

Aluede, O., Imonikhe, J., \& Afen-Akpaida, J. (2007). Towards a conceptual basis for understanding developmental guidance and counselling model. Education, 128(2).

Ajowi, J. O. (2005). Role of guidance and counselling in promoting students' discipline in public secondary schools in Bondo District. Unpublished M. Ed. thesis, Maseno University.

Ajowi, J. O. and Simatwa, E. M. W. (2010). The role of guidance and counselling in promoting pupil discipline in secondary schools. Department of Educational Management and Foundations, Maseno University, Kenya

Bakda, A. (2004). Effective guidance and counselling programmes for elementary schools. A working paper for the Amherst Schools community. 
Maina Samuel Gitonga, Enos Barasa Mukadi, Prisca Tarus-Kiptoo

THE INFLUENCE OF ADMINISTRATORS' PERCEPTION OF THE CHILDREN ACT 8 OF 2001

ON THE IMPLEMENTATION OF THE GUIDANCE AND COUNSELLING PROGRAMME

IN PUBLIC PRIMARY SCHOOLS IN EAST POKOT SUB-COUNTY, BARINGO COUNTY, KENYA

Boitt, M. L. J. (2016). Evaluation of the implementation of guidance and counselling programme aspects in Baringo county extra secondary schools, Kenya (Doctoral dissertation, Egerton)

Egbochuku, E. O. (2008a). Assessment of the Quality of Guidance and Counselling Services to Students' Adjustment in Secondary Schools in Edo State of Nigeria. Research Journal of International Studies, 8, 42-50.

Egbochuku, E. O. (2008b). Guidance and Counselling: A Comprehensive Text. Benin City: University of Benin Press.

MoEST (2001). Report on the Task Force on Student Indiscipline and Unrest in Secondary Schools. Jomo Kenyatta Foundation.

MoEST (2004). Report on the Task Force on Student Indiscipline and Unrest in Secondary Schools. Jomo Kenyatta Foundation

Republic of Kenya (2001). Report of the task Force on students' discipline and unrest in Secondary School. Nairobi, Kenya: Jomo Kenyatta Foundation.

Republic of Kenya (2002). The Children Act. Nairobi, Government Printer.

Republic of Kenya (2007). Kenya Vision 2030. Government Printer.

Republic of Kenya (2010). The Constitution of Kenya, Nairobi, Government Printer.

Republic of Kenya (2012). Taskforce's Report on the realignment of the Education Sector to the Constitution of Kenya 2010.

Republic of Kenya (2013). The Basic Education Act. Nairobi, Government Printer.

Republic of Kenya (2011). Prof. Douglas Odhiambo Task Force 2011. Nairobi: Government Printer.

Republic of Kenya (2012). Sessional Paper No. 14 of 2012: A policy framework for education and training. Nairobi: Government Printer.

Republic of Kenya (2014). Dr. Kilemi Mwiria Task Force Report 2014. Nairobi: Government Printer.

Republic of Kenya (2018). Ministry of Education National Education Sector Strategic Plan for the period 2018 - 2022. Nairobi: Government Printer.

Republic of Kenya (2019). Ministry of Education Sessional Paper NO. 1 OF 2019 on A Policy Framework for Reforming Education and Training for Sustainable Development in Kenya. Nairobi: Government Printer.

Riechi, A. R. (2020). The Education System of Kenya: Philosophy, Vision, and Mission. The Education Systems of Africa, 1-15.

Symonides, J. (2018). The United Nations Educational, Scientific and Cultural Organization (UNESCO) and the Promotion and Protection of Human Rights. The Universal Declaration of Human Rights: Fifty Years and Beyond, 45. 
Maina Samuel Gitonga, Enos Barasa Mukadi, Prisca Tarus-Kiptoo

THE INFLUENCE OF ADMINISTRATORS' PERCEPTION OF THE CHILDREN ACT 8 OF 2001

ON THE IMPLEMENTATION OF THE GUIDANCE AND COUNSELLING PROGRAMME

IN PUBLIC PRIMARY SCHOOLS IN EAST POKOT SUB-COUNTY, BARINGO COUNTY, KENYA

Creative Commons licensing terms

Author(s) will retain the copyright of their published articles agreeing that a Creative Commons Attribution 4.0 International License (CC BY 4.0) terms will be applied to their work. Under the terms of this license, no permission is required from the author(s) or publisher for members of the community to copy, distribute, transmit or adapt the article content, providing a proper, prominent and unambiguous attribution to the authors in a manner that makes clear that the materials are being reused under permission of a Creative Commons License. Views, opinions and conclusions expressed in this research article are views, opinions and conclusions of the author(s). Open Access Publishing Group and European Journal of Education Studies shall not be responsible or answerable for any loss, damage or liability caused in relation to/arising out of conflicts of interest, copyright violations and inappropriate or inaccurate use of any kind content related or integrated into the research work. All the published works are meeting the Open Access Publishing requirements and can be freely accessed, shared, modified, distributed and used in educational, commercial and non-commercial purposes under a Creative Commons Attribution 4.0 International License (CC BY 4.0). 